\title{
Inhaled nitric oxide for critically ill Covid-19 patients: a prospective study
}

\author{
Osama Abou-Arab ${ }^{1 *} \mathbb{D}$, Pierre Huette ${ }^{1}$, Fanny Debouvries ${ }^{1}$, Hervé Dupont ${ }^{1}$, Vincent Jounieaux ${ }^{2}$ \\ and Yazine Mahjoub ${ }^{1}$
}

Dear editor,

The role of inhaled nitric oxide (iNO) in the management of severe hypoxia due to coronavirus disease 2019 (Covid-19) is a subject of debate. Despite the lack of clinical data, the surviving sepsis campaign recommended the use of iNO as a rescue therapy in such patients with persistent hypoxemia and, at the same time, reminded that this treatment must be tapered off in the absence of rapid improvement [1].

The aim of the present study is to record the effect of iNO administration in COVID-19 patients with severe pneumonia.

We conducted a single-center prospective study at Amiens Hospital University (France), (ancillary study of a prospective COVID-19 critically patient database registered on ClinicalTrials.gov: NCT04354558 and declared to the CNIL number: PI2020_843_0026).

The population study was conducted on adults admitted in our intensive care unit for a COVID-19 severe pneumonia defined according to the WHO case definition [2]. All patients underwent a chest $\mathrm{CT}$ scan before iNO administration.

We administered 10 ppm of iNO (Kinox, Air Liquid Healthcare, Canada) through the inspiratory limb of the ventilator tubing when $\mathrm{PaO}_{2} / \mathrm{FiO}_{2}$ ratio was under 150 according to our local protocol management. Response to iNO was defined as an increase in $\mathrm{PaO}_{2} / \mathrm{FiO}_{2}$ over $20 \%$ during over $30 \mathrm{~min}$ following its administration. In

\footnotetext{
*Correspondence: osama.abouarab@gmail.com

${ }^{1}$ Department of Anaesthesiology and Critical Care Medicine, Amiens

Picardie University Hospital, 1 rue du Professeur Christian Cabrol, 80054 Amiens, France

Full list of author information is available at the end of the article
}

the absence of response to iNO administration, patients received one session of prone positioning. The following respiratory parameters were collected at baseline and after 15 to $30 \mathrm{~min}$ of iNO administration: positive end expiratory pressure (PEEP), respiratory lung compliance (RS compliance), driving pressure, fraction in inspired oxygen $\left(\mathrm{FiO}_{2}\right), \mathrm{PaO}_{2}, \mathrm{PaCO}_{2}$ and the echocardiographic presence of an acute cor pulmonale (ACP).

Data were presented as median [interquartile range] or as number (percentage). Responders group and non-responders group were compared using Wilcoxon-Mann-Whitney, chi-2 or Fischer exact test, as appropriate. Statistical tests were performed using SPSS software version 24 . A $P$ value under 0.05 was considered as significant.

From 1st of March to 31st of May 2020, 34 of 80 patients with COVID-19 severe pneumonia received iNO. Twenty-two of 34 patients $(65 \%)$ were responders and twelve were non-responders (35\%). After iNO administration, PEEP, RS compliance and driving pressure remained un 1

changed both in responders and in non-responders. At baseline, $\mathrm{PaO}_{2} / \mathrm{FiO}_{2}$ was significantly lower in the responders group in comparison with the non-responders group (respectively, 70 [63-100] vs 134 [83-173]; $P<0.0001)$ and was similar between groups after iNO administration $(P=0.068) . \mathrm{PaCO}_{2}$ levels were comparable between groups at baseline and after iNO administration. Prone positioning was not performed in the responders group.

We found a response rate of $65 \%$ to iNO administration. Our results differ from two recent reports on iNO use in COVID-19 in which the authors concluded in the

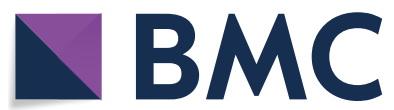

(c) The Author(s) 2020. Open Access This article is licensed under a Creative Commons Attribution 4.0 International License, which permits use, sharing, adaptation, distribution and reproduction in any medium or format, as long as you give appropriate credit to the original author(s) and the source, provide a link to the Creative Commons licence, and indicate if changes were made. The images or other third party material in this article are included in the article's Creative Commons licence, unless indicated otherwise in a credit line to the material. If material is not included in the article's Creative Commons licence and your intended use is not permitted by statutory regulation or exceeds the permitted use, you will need to obtain permission directly from the copyright holder. To view a copy of this licence, visit http://creativecommons.org/licenses/by/4.0/. The Creative Commons Public Domain Dedication waiver (http://creativeco mmons.org/publicdomain/zero/1.0/) applies to the data made available in this article, unless otherwise stated in a credit line to the data. 
absence of effectiveness of iNO [3, 4]. However, Tavazzi et al. found a positive effect in patients with ACP suggesting an effect of iNO on pulmonary circulation. Our results do not confirm this finding regarding the similar rate of ACP in the two groups. Among mechanisms of hypoxemia in COVID-19 patient, the presence of an intra-pulmonary shunt has been suggested [5]. In such hypothesis, the administration of iNO might worsen the shunt related to the pulmonary vasodilatation and might partially explain the decrease in $\mathrm{PaO}_{2} / \mathrm{FiO}_{2}$ in non-responders (Table 1). Regarding the $\mathrm{CT}$ scan features, we did not find any difference between groups, and thus, the absence of response to iNO could not be attributed to an increase "perfusion" of extensive ground glass opacities in non-responders.

Table 1 Data comparisons for responders and non-responders at baseline and after 15 to 30 min of nitric oxide (iNO) inhalation

\begin{tabular}{|c|c|c|c|}
\hline Variables & Non-responder $(n=12)$ & Responder $(n=22)$ & $P$ value \\
\hline \multicolumn{4}{|l|}{$\mathrm{PaCO}_{2}(\mathrm{mmHg})$} \\
\hline Baseline & $49[36-56]$ & $48[42-60]$ & 0.363 \\
\hline After iNO & $47[42-60]$ & $47[38-52]$ & 0.444 \\
\hline$P$ value before/after iNO & 0.581 & 0.067 & \\
\hline \multicolumn{4}{|l|}{$\mathrm{PaO}_{2}(\mathrm{mmHg})$} \\
\hline Baseline & 134 [80-160] & 65 [58-86] & $\leq 0.0001$ \\
\hline After iNO & $72[68-108]$ & $92[73-131]$ & 0.110 \\
\hline$P$ value before/after iNO & $<0.009$ & $<0.0001$ & \\
\hline \multicolumn{4}{|l|}{$\mathrm{PaO}_{2} / \mathrm{FiO}_{2}$} \\
\hline Baseline & 134 [83-173] & $70[63-100]$ & $\leq 0.0001$ \\
\hline After iNO & $125[92-144]$ & 144 [107-175] & 0.068 \\
\hline$P$ value before/after iNO & 0.005 & $<0.0001$ & \\
\hline \multicolumn{4}{|l|}{$\mathrm{FiO}_{2}$} \\
\hline Baseline & $0.8[0.7-0.9]$ & $0.95[0.7-1.0]$ & 0.168 \\
\hline After iNO & $0.75[0.65-0.90]$ & $0.70[0.6-0.8]$ & 0.557 \\
\hline$P$ value before/after iNO & 0.399 & 0.002 & \\
\hline \multicolumn{4}{|l|}{ PEEP $\left(\mathrm{cmH}_{2} \mathrm{O}\right)$} \\
\hline Baseline & $12[10-12]$ & $12[9-15]$ & 0.790 \\
\hline After iNO & 12 [10-13] & $13[9-15]$ & 0.486 \\
\hline$P$ value before/after iNO & 1.000 & 0.337 & \\
\hline \multicolumn{4}{|l|}{ Driving pressure $\left(\mathrm{cm} \mathrm{H}_{2} \mathrm{O}\right)$} \\
\hline Baseline & $15[14-17]$ & $16[14-17]$ & 0.209 \\
\hline After iNO & $14[13-16]$ & 13 [13-16] & 1.000 \\
\hline$P$ value before/after iNO & 0.221 & 0.098 & \\
\hline \multicolumn{4}{|l|}{ RS compliance $\left(\mathrm{ml} \mathrm{cmH} \mathrm{CO}_{2} \mathrm{O}^{-1}\right)$} \\
\hline Baseline & $30.0[21.8-36.7]$ & $26.6[20.2-31.8]$ & 0.534 \\
\hline After iNO & $33.9[24.7-37.0]$ & $30.0[22.1-33.4]$ & 0.407 \\
\hline$P$ value before/after iNO & 0.345 & 0.073 & \\
\hline $\mathrm{ACP}, n(\%)$ & $4(33)$ & $6(27)$ & 0.714 \\
\hline Prone positioning after iNO, $n(\%)$ & $7(58)$ & $0(0)$ & $<0.0001$ \\
\hline \multicolumn{4}{|l|}{ CT scan features } \\
\hline GGO & $10(83)$ & $20(91)$ & 0.602 \\
\hline Consolidation & $6(50)$ & $14(64)$ & 0.487 \\
\hline ICU mortality, n (\%) & $5(42)$ & $8(36)$ & 1.000 \\
\hline
\end{tabular}

Change over time within groups was determined by Wilcoxon signed rank test ( $P$ value before/after iNO) and between groups were determined by Mann-Whitney test ( $P$ value)

PEEP positive end expiratory pressure, $A C P$ acute cor pulmonale, $R S$ respiratory system, $\mathrm{FiO}_{2}$ inspired fraction in oxygen, $G G O$ ground glass opacities, $G G O$ ground glass opacities, CT scan computerized tomography scanner, ICU intensive care unit 


\section{Conclusion}

If iNO improves $\mathrm{PaO}_{2} / \mathrm{FiO}_{2}$ ventilation/perfusion in the majority of COVID-19 patients with severe pneumonia, the causes of unresponsiveness to iNO remain unclear.

\section{Abbreviation}

iNO: Inhaled nitric oxide.

\section{Acknowledgements}

None.

\section{Authors' contributions}

OAA, VJ, HD and YM were responsible for the study conception and manuscript draft. FD and PH collected data. All authors read and approved the final manuscript.

\section{Funding}

Only institutional funds were used for this study.

\section{Availability of data and materials}

Available on request.

\section{Ethics approval and consent to participate}

The study was approved by Amiens Hospital University and declared at CNIL (registration number: PI2020_843_0026). Oral and written information was delivered to the patients. No written consent was required.

\section{Consent for publication}

Not applicable.

\section{Competing interests}

The authors declare that they have no competing interests.

\section{Author details}

${ }^{1}$ Department of Anaesthesiology and Critical Care Medicine, Amiens Picardie University Hospital, 1 rue du Professeur Christian Cabrol, 80054 Amiens, France.

${ }^{2}$ Respiratory Department, Amiens Picardie University Hospital, 80054 Amiens, France.

Received: 3 September 2020 Accepted: 3 November 2020

Published online: 12 November 2020

\section{References}

1. Alhazzani W, Møller MH, Arabi YM, Loeb M, Gong MN, Fan E, et al. Surviving sepsis campaign: guidelines on the management of critically ill adults with coronavirus disease 2019 (COVID-19). Crit Care Med. 2019;2020:1.

2. Wu Z, McGoogan JM. Characteristics of and important lessons from the Coronavirus Disease 2019 (COVID-19) Outbreak in China: summary of a report of 72314 cases from the chinese center for disease control and prevention. JAMA. 2020;323:1239.

3. Tavazzi G, Marco P, Mongodi S, Dammassa V, Romito G, Mojoli F. Inhaled nitric oxide in patients admitted to intensive care unit with COVID-19 pneumonia. Crit Care. 2020;24:508.

4. Ferrari M, Santini A, Protti A, Andreis DT, lapichino G, Castellani G, et al. Inhaled nitric oxide in mechanically ventilated patients with COVID-19. J Crit Care. 2020;60:159-60.

5. Mahjoub Y, Rodenstein DO, Jounieaux V. Severe Covid-19 disease: rather AVDS than ARDS? Crit Care. 2020;24:1-2. https://doi.org/10.1186/s1305 4-020-02972-W.

\section{Publisher's Note}

Springer Nature remains neutral with regard to jurisdictional claims in published maps and institutional affiliations.
Ready to submit your research? Choose BMC and benefit from:

- fast, convenient online submission

- thorough peer review by experienced researchers in your field

- rapid publication on acceptance

- support for research data, including large and complex data types

- gold Open Access which fosters wider collaboration and increased citations

- maximum visibility for your research: over $100 \mathrm{M}$ website views per year

At BMC, research is always in progress.

Learn more biomedcentral.com/submissions 